\title{
Quantifying government media relations in Queensland
}

\author{
Mark PEARson ANd Hamish MCLEan* \\ Bond University
}

\begin{abstract}
This article draws upon historical and contemporary data to attempt to identify key issues in government media relations and to discuss the processes and challenges involved in attempting to quantify the expenditure on this activity in Queensland in the modern era. A combination of investigative journalism and academic research methods have been used to position Queensland Government media relations as a practice and to gauge expenditure, staffing, and cost to the taxpayer. The Electoral and Administrative Review Commission's Report on Review of Government Media and Information Services was the first comprehensive measure of such costs and since then only some insights were offered by Premiers Beattie and Bligh in 2006 and 2008 in response to parliamentary questions on notice. This article reviews these costs, canvasses expert estimates of the real cost of government media relations and debates some of the competing interests at stake.
\end{abstract}

\section{Introduction}

Public relations activities within the public sector - commonly described as 'government media relations' - have been the subject of considerable academic attention in recent years, as chronicled by Pearson and Patching (2008). Much of the criticism of public relations generally has been levelled at how practitioners frame information for the benefit of their clients or organisations. The government sector is a significant employer of public relations practitioners in Australia. A national survey of 322 practitioners found that the government was the second-highest employer of public relations practitioners $(29.4 \%)$ that was not too far behind private consultancies (33.8\%) (de Bussy \& Wolf, 2009). Strategic communication counsel and media relations were listed in the top three daily duties.

Within the public sector, the practice is deserving of greater scrutiny as it is funded from the public purse. It has been labelled 'spin doctoring' and criticised for the blurring the boundaries between the promotion of an incumbent government's political agenda and the public service role of effective factual communication to benefit the citizenry (Louw, 2005; Stockwell, 2007). Given that research has found that the murky relationship between the political and departmental public relations activities is largely undocumented in an empirical sense, this article attempts to quantify the scale of media relations in a selected State Government.

\section{Methodology}

A combination of investigative journalism and academic research methods has been used to gauge expenditure, staffing, and cost to the taxpayer of government media relations in Queensland. Co-author of this paper, Mark Pearson used investigative journalism research methods when conducting a $\$ 110,000$ funded academic research project for the Australian Broadcasting Authority in 2000, and described the use as follows: 
Stage One offers a multi-method approach to the research task, building upon the significant findings of previous research with a combination of journalistic and social science investigative approaches. Given the broad-ranging requirements of the Revised Project Brief ... It was decided that Stage One required a combination of methods, including ...

The gathering and input of ownership, production and syndication data on news and current affairs services and parent corporations into the qualitative software database NUD*IST. This drew upon academic and journalistic research skills in locating data in traditional sources and in following other leads through journalistic inquiry (ABA, 2001, p. 31).

The research team's original tender proposal for the project described the use of journalism as a research technique as follows:

This Stage One proposal suggests a multi-method approach to the research task, building upon the significant findings of previous research with an imaginative and effective combination of journalistic and social science investigative approaches. The use of a journalistic research method in such a project is a deliberate one, based on the premise that the timelines and breadth of data will require a researcher with the ability to draw upon existing relationship networks and maintain a clarity of vision and task orientation. Several of the research tasks lend themselves to the modus operandi and vitae of an investigative journalist, familiar with the media environment, corporate structures, financial documentation, interviewing skills, online research techniques, confidentiality protocols, and with the ability to refocus and respond to the pressure of deadlines and the shifting demands of data (Bond University Centre for New Media Research and Education, 2000, pp. 5-6).

It is a State with an important historical background to the exploration of an incumbent government's potential use of its public relations resources for political ends. The Electoral and Administrative Review Commission's Report on Review of Government Media and Information Services in 1993 was the first comprehensive measure of such costs. Since then, only some insights have been offered by premiers Beattie (Wenham, 2006) and Bligh (Lion, 2008) in response to parliamentary questions on notice. This article reviews these costs, canvasses expert estimates of the real cost of government media relations in this state, and debates the competing interests at stake: the public interest in citizens receiving factual government communication and an incumbent government's desire to portray its endeavours to the best political advantage.

\section{Public sector public relations today}

Scholars assert that the public relations industry has matured from its conception in the late 1800 s and early 1900s as headline-grabbing 'publicity at any cost' to a more rounded approach of relationship building and two-way symmetrical communication (Johnston \& Zawawi, 2009; Lattimore et al., 2009). This is reflected in the way that the industry's professional body, the Public Relations Institute of Australia, defines public relations as "the deliberate, planned and sustained effort to establish and maintain mutual understanding between an organisation (or individual) and its (or their) publics". It acknowledges, however, that those working in the public sector are sometimes labelled 'spin doctors', an issue discussed further in this paper, and counters that its code of ethics and conduct "ensure members always behave according to the highest standards of our industry" (PRIA, 2010). The reliance on codes to uphold standards perhaps may not be needed, at least in the UK, where Gregory found that public sector communicators were not motivated by power or money: "They are in service because they want to make a difference in society. This societal commitment is very strong and permeates both thinking and behaviour" (2008, p. 220). 
In the Australian context, Glenny found that experienced government public relations practitioners regarded their role as "engagement with the public", while noting that their lesser experienced colleagues "viewed the function as one of persuasion and dissemination" (2008, p. 152). L'Etang (2009) points out that public relations is about managing organisational relationships and reputation (p. 609) and its activities "typically cluster around centres of power and processes of change". This situation has prompted L'Etang to warn: "Such a close alliance between power and managed communication could be defined as propaganda rather than PR" $(2009$, p. 615). This is the elephant in the room in any discussion of the value of public expenditure on government media relations. It begs the question: is such a budget line in almost every government department and quasi-governmental body defensible because of its public communication function or does L'Etang's 'propaganda' concern lessen its claim to being a justifiable public expense? Further, is there a way of decoupling the public service aspect of government media relations from its 'spin' or 'propaganda' persona?

Esser et al. noted that the media relied on material generated by the public relations industry and that the term 'spin doctor' was used by journalists to "demonise any kind of professional PR" (2001, p. 39) Johnston (2007, p. 7) adopted a similar approach, noting that public relations and spin-doctoring went hand-in-hand when it came to an often fragile relationship with journalists. It is a term no stranger to media headlines in Australia: Sydney's Daily Telegraph trumpeted "Millions spent on spin doctors" (Silmalis, 2010), while Brisbane's Sunday Mail revealed $\$ 49 \mathrm{~m}$ for PM's spin doctors, noting the cost of the Federal Government's 418 media advisers, media monitoring and 'PR spin' (2009, p. 24). While public relations might be disparaged by journalists, few could dispute its impact on the employment market for media professionals and on the news agenda each day.

\section{Research questions}

The key question for the purposes of this project - how might a government's expenditure on media relations be measured? - remains difficult to answer given the lack of attention by researchers. In one of the few studies, Ward (2003) found that that political communication in Australia was not well understood, given the blurred lines between political minders and departmental public affairs sections. Stockwell (2007) drew a 'Chinese wall' between what he termed 'political spin-doctors' or 'minders' and 'departmental information officers', who were primarily involved in public education activities. However, Stockwell suggested departmental staff could be "drawn into the work of spin" (2007, p. 132). Such a situation was not ruled out by Ward (2003) who suggested that anecdotal evidence, such as the 2001 'children overboard' case, pointed to the political benefits derived from the public relations resources within the public service.

Gordon argued governments must engage communication practitioners in order to get their voices heard on a crowded media stage, arguing that it 'can only enhance their accountability and strengthen the public's trust' (2000, p. 309). The danger of spin penetrating Stockwell's 'Chinese wall' became evident in the UK when the Independent Review of Government Communications noted:

The breakdown in the level of public trust in, and credibility of, government communications and the disengagement from the political process pose questions to politicians and to the media as to how they conduct their legitimate, but very different, roles and responsibilities (Phillis, 2004, p. 2). 
A key finding centred on the 'lack of clarity' in the relationship between political media advisors, termed 'special advisers', and civil servants. In acknowledging both needed to work together, the inquiry determined that the seemingly separate roles were in fact fraught with tension.

\section{Measuring government media relations in Queensland}

Patching and Pearson (2007) offered a rationale for research and publication in the field, and found a lack of empirical data about Australian government media relations, arguing:

A study of government media relations is important given the public expenditure on the enterprise and the fact that it is positioned squarely between the important democratic institutions of government and the media. Its effective and transparent operation is essential to an informed citizenry. Access to information is a key ingredient of democracy, reinforced in decisions by our highest courts. Citizens have a right to understand the processes of governmental information dissemination being used to influence them and also to understand the public expenditure on that endeavour (Patching \& Pearson, 2007, p. 1).

This article reports upon an attempt to develop a process for quantifying such expenditure. As stated earlier, the Electoral and Administrative Review Commission's 1993 review of government media and information activities was the first comprehensive measure of the cost and processes of government media relations in Queensland. That inquiry was the first and only major governmental review of the sector, and resulted from recommendations from corruption commissioner Tony Fitzgerald (Fitzgerald, 1989). It is worth quoting Fitzgerald's comments on the topic:

It is legitimate and necessary for Government Ministers, departments and instrumentalities to employ staff to help ensure the public is kept informed. Media units can also be used, however, to control and manipulate the information obtained by the media and disseminated to the public. Although most Government-generated publicity will unavoidably and necessarily be politically advantageous, there is no legitimate justification for taxpayers' money to be spent on politically motivated propaganda. The only justification for press secretaries and media units is that they lead to a community better informed about Government and departmental activities. If they fail to do this then their existence is a misuse of public funds, and likely to help misconduct to flourish (Fitzgerald, 1989, p. 142).

The passage encapsulates the inevitable tension in the domain of government media relations in a modern democracy - that between the genuine public interest in citizens receiving important information from their governments and those citizens not being misinformed by partisan promotion of an incumbent political party. Fitzgerald's recommendation 10 (h) was that a new Electoral and Administrative Review Commission (EARC) be charged in part to formulate "guidelines for monitoring the costs and activities of ministerial and departmental media units and press secretaries by an all-party Parliamentary Committee" (Fitzgerald, 1989, p371). Two bodies subsequently inquired into the matter - firstly, the Electoral and Administrative Review Commission, which in 1993 produced the 273-page report referred to earlier, and the Legislative Assembly of Queensland's 92-page review of the EARC processes and recommendations, published a year later (Parliamentary Committee for Electoral and Administrative Review, 1994). Those documents, researched with access to public service files and in a post-Fitzgerald climate of relative bureaucratic co-operation, offered unprecedented insights into the scale, techniques and impact of government media relations in Queensland. Sadly, the passage of time, the increasing sophistication of 
government media relations, and its integration into so many areas of government enterprise, means that any attempt to garner comparative data 15 years later is fraught, if not impossible.

This article explains that difficulty and offers some insights into the scale of government media relations in the administration of the same state in the modern era. Those Queensland inquiries also recommended a new framework for the administration of government media relations, encapsulated in more than 42 recommendations (and many more subrecommendations) from EARC in 1993 and endorsed or adapted recommendations by the ensuing parliamentary committee in 1994 (Parliamentary Committee for Electoral and Administrative Review, 1994, Appendix C). Some of these promoted equity and transparency, such as the recommendation for the annual reporting on the costs and activities of ministerial and departmental media and information units and that all media outlets have equal access to government press conferences and briefings. Some, however, had the potential to stem or channel the flow of public information, such as the requirement that former public servants not disclose confidential information; that personnel duty statements be reviewed to determine the "appropriate level of authority for the release of official information"; and that government communication and information campaigns be coordinated by the Premier's Department.

Grundy (1993) offered a useful summary of the EARC inquiry, particularly on the issue of media reliance upon government press releases. He noted the Queensland Government had been using spurious media management techniques, including:

- $\quad$ Sometimes giving newspaper reporters a story late in the day so television and radio missed out;

- $\quad$ Giving stories to television reporters days in advance, while promising to withhold it from newspapers until after it had been screened;

- $\quad$ Public reprimands of journalists who dared to criticise the government; and

- $\quad$ Press secretaries planning ministerial trips around the facilities and links available for television crews (Grundy, 1993, p. 293).

It is not surprising such activity seems to fall in line with the 'below-the-line' spin-doctoring tactics identified by Gaber (2000).

The EARC research on the cost of government media relations is particularly relevant to this study. The inquiry established that the Queensland government's total expenditure on public relations and other promotional information programs including advertising campaigns in 1991-92 was \$36.577 million involving 273 staff (EARC, 1993, Appendix J, p. 148). "The Commission believes that this figure represents a conservative estimate of what the Government spends on public relations and media liaison in departmental activities," the report stated (EARC, 1993, p. 194). Put another way, the EARC report found that the Queensland Government was the biggest employer of journalists in the state (cited in Orr, 1994, p. 107). Once advertising placements and salaries of $\$ 21.48$ million were deducted from the total, it left a balance of $\$ 15.1$ million spent on media and public relations, publications, special events and consultants at the time. If you then deducted the expenditure on consultants of $\$ 1.68$ million, it would leave $\$ 13.42$ million of departmental staffing and resources being expended on such activities. In its account of the cost of government media and information services, even EARC, which had the full co-operation of the public service, reported discrepancies in the information gathering and reporting process. The Commission 
found it was out of synch with the Treasury Department on several calculations, amounting to a \$4.1 million difference overall (EARC, 1993, p. 194). The Commission commented:

The discrepancies may have resulted from some misunderstanding by departments as to what categories of staff that (sic) were to be included. But the other major and obvious discrepancies occurred in the information concerning expenditure on communication or creative consultants (EARC, 1993, p. 195).

We will return to such accounting difficulties later in this article.

\section{The 'corporate' approach}

Both the EARC inquiry and the subsequent parliamentary committee recommended guidelines making explicit "that the purpose of government publications is the provision of relevant information and not promotion of government or 'corporate' image" (Parliamentary Committee for Electoral and Administrative Review, 1994, Appendix C6). Winding the clock forward 16 years, however, we find that most of the recommendations encouraging transparency of government media relations have been ignored and a perusal of state government department and agency annual reports reveals they indeed have a 'corporate' feel about them.

Documents available from the Department of Premier and Cabinet are a case in point. Despite the fact that this body is ultimately responsible for the whole-of-government media policy, there is miniscule identifiable media and information services data available in its key reports. Overall, it makes a mockery of the warning against 'corporate' image. In October 2008, the department's website had listed its annual report, budget service delivery statement and strategic plan under the heading 'Corporate Reports' (Queensland Government A, 2008). A check two years later found the link had been deleted.

Yet delving into such reports is instructive as to the positioning of media and information tasks within such an entity. The department's organisation chart (Table 1) features a Communication Services unit under the State Services section of the Governance Division of the Office of the Deputy Director-General. Its description also promoted that 'corporate' feel in its 2008 version.

\section{Communication Services}

Communication Services provides strategic and operational services to the Premier and key portfolio clients. This includes advice on advertising, marketing and communication strategies and development of a wide range of communication-related products and services. The unit also provides direction, coordination and leadership to government agencies concerning communication policies and initiatives. Communication Services is responsible for publishing Sectorwide, Catalyst Queensland and Community Cabinet News, and well as providing advice on the Queensland Government Corporate Identity (Queensland Government, 2008 B). Interestingly, that description had also been removed from the department's website by July 2010, although the description of the Deputy DirectorGeneral's role still used the 'corporate' word: “As Deputy Director-General, Governance, Pat Vidgen is responsible for leading the delivery of executive and corporate support services for the Premier and other departments" (Queensland Government C, 2010). 


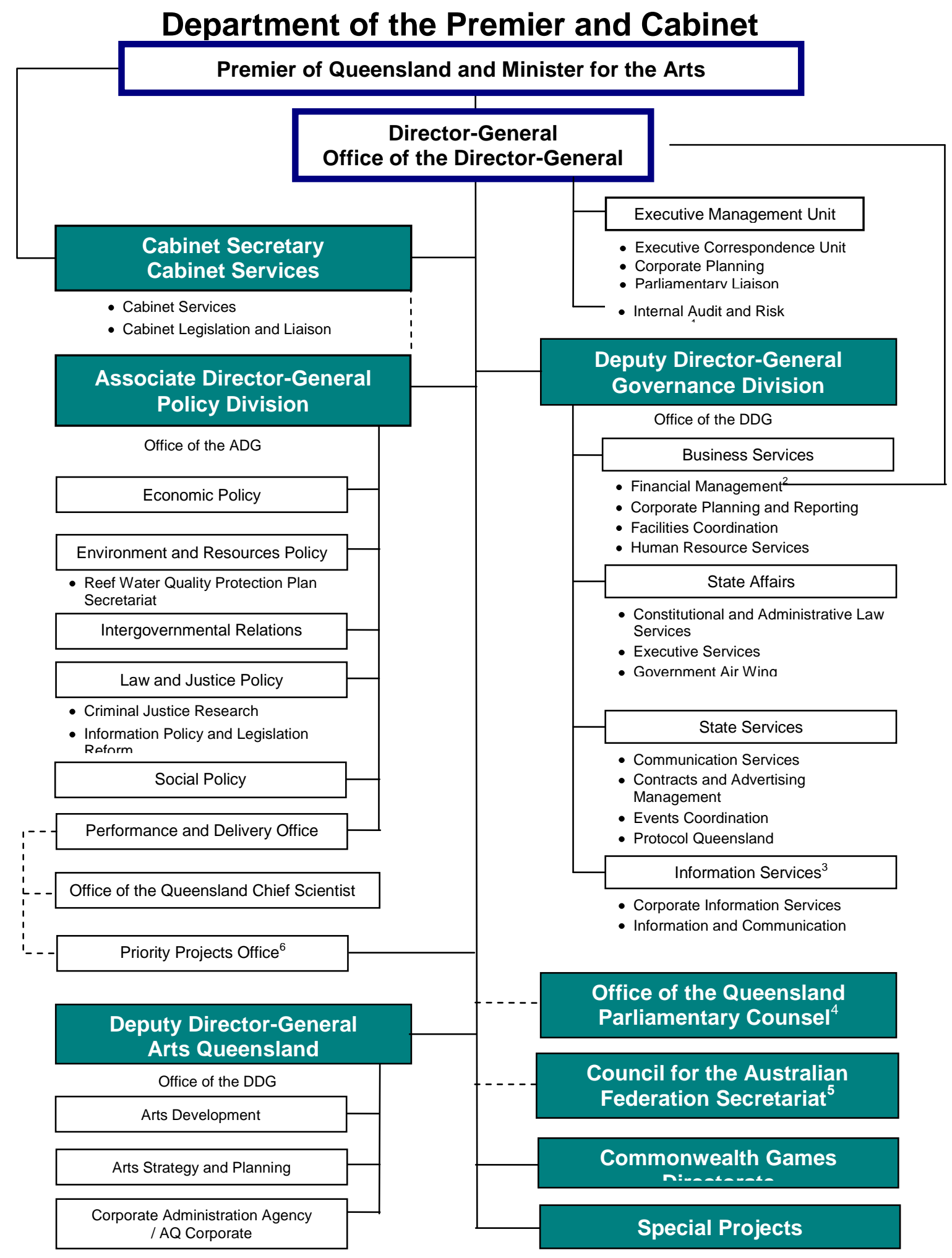

Notes:

1 Internal Audit and Risk Services report to the Director-General but is administratively responsible through the Deputy Director-General, Governance.

2 Financial Management report to the Director-General but is administratively responsible through the Deputy Director-General, Governance.

3 Information Services report to the Director-General on whole-of-Government chief information office related matters.

The Office of the Queensland Parliamentary Counsel report to the Director-General for matters governed by the Financial Accountability Act 2009.

5 The Council for the Australian Federation Secretariat report to all State and Territory First Ministers but is administratively responsible through the DirectorGeneral.

Table 1: Queensland Department of the Premier and Cabinet organisational chart, July 2010. Available: http://www.premiers.qld.gov.au/about-us/our-structure.aspx 
Other documents, most notably those related to policy, indicated media and communication were key considerations in policy formation. For example, the Queensland Policy Handbook listed "the extent of media coverage" first among three key factors impacting upon the policy agenda (Director-General, 2000, 3.0). This, too had been removed from the website by July 2010, as evidenced by a notation at http://www.premiers.qld.gov.au/publications/categories/ policies-and-codes/handbooks.aspx.

Of course, any media relations expenditure of a Communications Services office in the Department of Premier and Cabinet is separate from the costs of media liaison performed from within the Premier's personal office and from outsourced public relations functions, a point made in coverage of 2008 revelations of media relations expenditure by the Bligh government (Lion, 2008).

The difficulties of putting a precise figure on government media relations in any particular government or governmental department were predicted in an earlier paper (Patching \& Pearson, 2007) and had already been highlighted in the EARC report cited above (EARC, 1993, pp. 194-195). Pearson and Patching introduced a research model known as the 'iceberg approach', a multi-level system of inquiry recognising that government documentation of expenditure on media relations would inevitably be under-stated because media functions of many public servants would not be ascertainable via their mere position descriptions or the domains of their departmental units. Queensland Premier Anna Bligh used this ambiguity as an excuse for not providing concrete figures when asked by the Opposition to specify how many staff in her government were "involved in public affairs, communications, graphic design, marketing or advertising duties?” She responded:

As you would be aware, it is the nature of the role of many public servants that their day-to-day activities inevitably involve engagement with the general public and/or communicating with the general public on the array of programs and activities funded by the government; on service delivery and information on the services available to the public; and on changes to laws and policy. In this respect, the vast majority of Queensland's 187,973 full time equivalent public servants are likely to be involved in these activities from time to time. For example, a police officer speaking at a neighbourhood watch meeting; a teacher aide developing material for use in a school newsletter; a school health nurse writing and designing information for parents; or a policy officer consulting with community representatives on draft legislation (Question on Notice No. 1149, 2008).

This itself raises both challenges and issues in the quantification of government media relations. If most public servants have media relations/communication as part of their job description, how can it be effectively quantified? The Premier was, however, more forthcoming in answering an earlier, more specific question, asking her to list by department the number of public servants whose jobs were dedicated to media or public relations. In her response, the Premier proceeded to quantify the 'tip of the iceberg' of Queensland Government resourcing of media relations, detailed in Table 2. She prefaced her answer with a statement clearly intended to distance the government media relations role from politically partisan 'spin':

Government departments facilitate, coordinate and manage a diverse range of communication activities that are designed to promote and communicate the Government's core programs, key priorities and initiatives, and encourage broad community participation. Public servants whose jobs are dedicated to media or public relations keep the public informed on matters such as public health education, road safety and law and order programs, court diversionary programs, responsible gambling education, housing assistance, foster carer recruitment, responsible 
parenting, public transport information, drought or flood assistance and important environmental information. (Question on notice, No. 685, 2008).

\begin{tabular}{|l|c|}
\hline Name of Department & $\begin{array}{c}\text { No. of full time } \\
\text { equivalent staff }\end{array}$ \\
\hline Department of Child Safety & 8 \\
\hline Department of Communities and Disability Services Queensland & 38 \\
\hline Department of Education, Training and the Arts & 24.9 \\
\hline Department of Emergency Services & 9 \\
\hline Department of Employment and Industrial Relations & 15.7 \\
\hline Department of Housing & 24.3 \\
\hline Department of Infrastructure and Planning & 6.5 \\
\hline Department of Justice and Attorney-General & 10.9 \\
\hline Department of Local Government, Sport and Recreation & 7 \\
\hline Department of Main Roads & 9 \\
\hline Department of Mines and Energy & 10 \\
\hline Department of Natural Resources and Water & 10 \\
\hline Department of the Premier and Cabinet & 20 \\
\hline Department of Primary Industries and Fisheries & 4 \\
\hline Department of Public Works & 16.1 \\
\hline Department of Tourism, Regional Development and Industry & 5.5 \\
\hline Environmental Protection Agency & 6 \\
\hline Queensland Corrective Services & 68.6 \\
\hline Queensland Health & 19 \\
\hline Queensland Police Service & 50 \\
\hline Queensland Transport & 4 \\
\hline Queensland Treasury & \\
\hline
\end{tabular}

Table 2: Number of Queensland public servants, by department, whose jobs are dedicated to media or public relations (separate from ministerial media advisers). Source: (Question on notice No. 685, 2008)

The Table 2 list amounted to a total of 367.5 full time equivalent positions in the Queensland public service engaged in media or public relations, quite separate from up to three ministerial media advisers to which the state's 19 government ministers are entitled in their own offices (The Queensland ministerial handbook, 2004).

The MyCareer website (2008) featured a salary centre averaging wages from job listings over the previous 90 days across various sectors. At October 13, 2008, its average listed salaries for the following sectors were:
Australian PR and Communications
$\$ 74,800$
Australian media relations
$\$ 88,610$
National government, public and regulatory affairs
$\$ 77,688$

The Queensland Government's own positions vacant site listed 12 full time communication or media positions at October 13, 2008 with the following titles and minimum annual salaries:
Assistant Director - Communication
Communication officer
Communications officer
Senior media officer
$\$ 68,693$ 


$\begin{array}{ll}\text { Media officer } & \$ 59,969 \\ \text { Principal communications officer } & \$ 99,264 \\ \text { Senior communications and media officer } & \$ 77,584 \\ \text { Principal communications officer } & \$ 87,005 \\ \text { Senior communications officer (media) } & \$ 77,584 \\ \text { Senior communications officer } & \$ 77,584 \\ \text { Communications officer (media) } & \$ 68,693 \\ \text { Senior communication officer } & \$ 68,693\end{array}$

The average was $\$ 76,392$ for the 12 advertised positions in the field. A similar search of media or communication positions in the Queensland Government on August 2, 2010, revealed a tighter job market for such positions, with the following titles and minimum annual salaries:

$\begin{array}{ll}\text { Assistant electorate officer } & \$ 50,125 \\ \text { Senior policy officer } & \$ 78,268 \\ \text { Public affairs officer } & \$ 68,414 \\ \text { Senior communications officer } & \$ 75,779 \\ \text { Principal communications officer } & \$ 84,793\end{array}$

The average minimum salary of these five positions was $\$ 71,475$, with an outlier temporary position at the lower end. The average of their maximum salaries was $\$ 76,180$, again with the outlier temporary position at the lower end.

This was lower with the MyCareer data listed above, but it would be fair to offer a conservative estimate of an average salary for a government-employed media, PR or communication officer at $\$ 75,000$ for the purposes of this calculation.

Using this as a base, it would mean the Queensland Government's expenditure on such officers' raw salaries alone in 2008 would be at least $\$ 75,000$ for the 367.5 positions the Premier said were media relations or public relations positions, totalling $\$ 27.56$ million. The Queensland Government calculates on-costs for every employee at 18\% (Queensland Government $D, 2008$ ) or $\$ 13,500$ each, bringing our total salaries bill to at least $\$ 32.5$ million per annum.

Yet even this is not the real cost of each public servant working in government media relations. There are costs attached to running an office. For an indication, we turned to the Auditor-General's office Annual Report for 2006-2007 and tallied the costs of supplies and services, including information technology and minor office equipment, insurance premiums, vehicle lease costs, rent and office services, staff development, travel costs and other administrative costs, which amounted to $\$ 10,876$ per employee per annum (Queensland Audit Office, 2007). This would add a further $\$ 4$ million to our total, bringing it to $\$ 36.5$ million to pay and sustain the government media relations staff on the state government's payroll.

State Government Ministers can have up to five media advisors on their staff (drawn from within the Queensland Public Service on leave without pay or from outside the public service), as detailed in the Ministerial Handbook (Queensland Government E). The handbook states: "To assist in determining staffing requirements, the staffing model below is suggested as a basis for Office requirements. 


$\begin{array}{lll}\text { Designation } & \begin{array}{l}\text { No.of } \\ \text { Positions }\end{array} & \text { Classification Level } \\ \text { Senior Policy Advisor } & 1 & \text { AO8-SO1 } \\ \text { Senior Media Advisor } & 1 & \text { AO8-SO1 } \\ \text { Policy Advisor/Media Advisor } & 2 & \text { AO6-AO7 } \\ \text { Assistant Policy/Media Advisor } & 2 & \text { AO4-AO5 } \\ \text { Personal Secretary/Office Manager } & 1 & \text { AO4-AO5 } \\ \text { Administrative Officer } & 2 & \text { AO1-AO3 } \\ \text { Chauffeur/Assistant } & 1 & \text { OO3" }\end{array}$

In August 2010, there were 18 state ministers. If each of these media advisor positions was filled, at the minimum classification level, it would amount to annual salaries of $\$ 59,270 \times 2$ $+\$ 78,811$ x $2+\$ 97,702=\$ 373,864$ per minister per annum x $18=\$ 6,729,552+18 \%$ oncosts $(\$ 1,211,319)=\$ 7,940,871$ (Education Queensland Salary Schedule). These extra 90 staff would bring to the total to 457.5 staff working in government media relations at a cost of at least $\$ 44.4$ million. This does not allow for the possibility if ministers' entitlements were increased for multiple portfolios or for an increased entitlement for the Premier.

Then there is the electoral office entitlement for each Member of Parliament. This is harder to calculate, and would require a formal audit of each of Queensland's 89 members of the Legislative Assembly and their 183 full-time equivalent electorate office staff. But assuming, for the sake of the exercise, based on a phone-around of electorate offices, that .5 of a position is allocated to media and public relations duties in each member's office, that would amount to a further 44.5 such positions state-wide. However, electorate officers typically earn less than the average media or communication officer in the broader public service. According to the Parliamentary Service Certified Agreement, their pay rates ranged from $\$ 45,962$ per annum through to $\$ 68,458$ at July 1, 2008 (Parliamentary Service Certified Agreement, 2007, p. 15). Averaging this, and adding our $18 \%$ on-costs would amount to $\$ 67,508$ per employee. Add the $\$ 10,876$ per employee in office expense costs and allowances, the new total would be $\$ 78,384$. Applying the same salary and expenses formula we have used above to the .5 positions per electorate office dealing with media matters, this would add another $\$ 3.5$ million to the state media relations cost, bringing the state total to \$47.9 million.

Inevitably, there would be more costs once outside consultancies were included and if we were to extend the study to government advertising and budgeted special promotional programs which was included in the calculations for the \$36.6 million for the EARC study in 1991-92 (cited in Grundy, 1993). It is worth noting that the EARC calculations were based on 191 media and policy advisers and that has increased to something more than 400 over the intervening 16 years.

In fact, there is firm evidence that our estimates have been significantly understated. Premier Bligh's predecessor, Peter Beattie, released figures in response to slightly broader questions asked by Opposition members of all but one minister between May and November 2006. Those questions asked ministers to detail:

1. the number of full-time and part-time staff employed by (department) in Public Affairs/Communications/Media Liaison and Public Relations positions, and

2. the total amount of wages/salaries paid to (department) staff in Public Affairs/ Communications/Media Liaison and Public Relations positions. 
Some questions also included a request for an account of graphic design staff. Totalled responses from ministers amounted to 528 people, with salaries amounting to $\$ 37.27$ million for the 2005-2006 financial year. Staff numbers from two portfolios (Education and Arts and Local Government, Planning and Sport) were omitted from the calculations (Wenham, 2006). That figure was also missing the 31 ministerial advisers employed at the time by the 18 ministers, which the Courier-Mail estimated as costing about \$2.5 million per annum.

Premier Bligh's most recent response (367.5 FTE position) was to a narrower question from then Opposition leader Lawrence Springborg who asked on April 30, 2008 (Question on notice, No. 685, 2008): "Will she list, by department, the number of public servants whose jobs are dedicated to media or public relations?" This question omitted mention of "public affairs", "communication" and "graphic design" roles, so did not offer a suitable comparison with the 2006 responses. Which brings us back to her refusal to go further when the Opposition attempted to broaden the question to get figures giving a direct comparison with the Beattie government's 2006 expenditure, using these very terms (Question on notice, No. 1149, 2008).

\section{Discussion and directions}

So where does all this leave the researcher attempting to quantify government media relations in a particular administration? As can be seen from the above efforts of the Queensland Opposition, any such attempt requires a pre-determined definition of government media activities, consistent to each audit period. Further, a precise account would require an examination of the job descriptions of all public servants whose roles involve some level of media relations and an estimate from them or their superiors of the proportionate time and effort they spent on media-related activities. It is unlikely this would be achievable, given the extent to which media/communication/public relations activities have permeated the management culture and operational systems of government in the modern era.

Thus, the challenge for researchers attempting any longitudinal study is to narrow their data sets to avoid comparisons of apples with oranges over different administrations.

Our best estimate from the above material, using the conservative EARC figures cited above and comparing them with the most recent Bligh Government figures, shows a growth of $272 \%$ from the 1991-1992 EARC figure of $\$ 13.4$ million to the $\$ 36.5$ million of pure departmental expenditure (excluding ministerial advisers and MPs' electorate office media activities) calculated above for 2008 (See Table 3).

\begin{tabular}{|l|l|}
\hline Year & Expenditure \\
\hline $1991-2$ & $\$ 13.4 \mathrm{~m}$ \\
\hline 2008 & $\$ 36.5 \mathrm{~m}$ \\
\hline
\end{tabular}

Table 3: Comparison of Queensland departmental expenditure on media relations and public relations over a 17 year period.

Of course, this is just one Australian state and a very conservative estimate which excludes several potential inclusions, such as ministerial advisers, advertising budgets, consultants fees and MPs' electorate officers. If the process is multiplied for every state and territory, and at local and federal levels, the total cost of government media relations nationally would amount to several hundreds of millions of dollars annually. 
Cold, hard statistics do offer some indication of the scale of the overall public relations enterprise. The sheer human resource power of the 400 plus individuals hired by the state government for media or public relations purposes can be given some perspective when it is compared with the following:

- The approximately 200 journalists at the Courier-Mail - the state's largest newspaper;

- the Australian Broadcasting Corporation's reported total 401 staff (not just journalists) working in Queensland in 2007 (ABC, 2007, p. 49);

- The 2590 individuals describing themselves as journalists in Queensland in the 2006 census (www.abs.gov.au, 2010);

- The 2335 individuals describing themselves as public relations professionals in Queensland in the 2006 census (www.abs.gov.au, 2010).

Just as in the Fitzgerald era two decades ago, the Queensland Government remains the largest employer of journalists in the State. The final two figures indicate there is now almost a public relations practitioner available to service every single journalist in Queensland.

\section{Conclusion and discussion}

There is, of course, a research challenge in the interpretation of any results. If it accepted that the current Queensland Government's annual expenditure on communication, public relations and media relations is something around $\$ 50$ million, is this necessarily a bad thing? Premier Bligh was at least partly right when she told Parliament the roles of a vast number of public servants involved communicating with the public (Question on notice, no. 1149, 2008). Few would argue with the need for governments to communicate with citizens on a range of topics, including such things as water restrictions, public health initiatives, road closures and school curriculum developments. We might call this genuine public information which might justifiably be regarded as an appropriate use of taxpayer funding. However, the alarm bells ring when governments are using those positions, and that expenditure, for political purposes and that becomes the challenge for researchers and takes the research enterprise into the qualitative domain. So, for example, if a public health campaign featured statements boasting the Bligh Labor Government's achievements and criticising the Opposition's policies on the matter and the printed materials or websites featured photographs of the Premier or Health Minister 'in action', 'looking after the interests of Queenslanders', do we categorise it as shameless 'spin' or should it still be classed as a necessary public information campaign?

We might work towards developing certain 'indicators' of 'spin' as opposed to governmentcitizen communication in the legitimate public interest. For example, are public servants in a particular administration free to talk to the media on issues within their purview, or do policies require them to channel media requests through a politically-driven Government filtering system? What power do ministerial media advisers (political appointees) hold over the media relations efforts of departmental communication officers (public servants)? And what judgments do we pronounce upon particular governments' expenditure on media relations? How do we contextualise, for example, the Queensland Government's circa \$50 million annual outlay? Is it unfair to look to other expenditure as an indication of the sorts of concrete accomplishments that might be achieved in its place? Accounting transparency, budget and policy priorities, research methods and community awareness of government media relations as a taxpayer-funded enterprise are just some of the issues and challenges facing us as we drill down with our quantification of government media relations and begin 
to analyse the techniques of its practitioners to determine whether they are genuine public service communicators or defacto political propagandists for an incumbent government.

\section{References}

ABC. (2007). Celebrating 50 years. Australian Broadcasting Corporation Annual Report 2007. Sydney: Australian Broadcasting Corporation.

Australian Bureau of Statistics (2006). Cat. No. 2068.0 - 2006 Census Tables. 2006 Census of Population and Housing. Queensland (State). OCCUPATION(a) (UNIT GROUPS) BY SEX. Retrieved from http://www.abs.gov.au/.

Bond University Centre for New Media Research and Education. (2000). Bond University Centre for New Media Research and Education: Unpublished ABA Proposal. Bond University.

De Bussy, N. and Wolf, J. (2009) The state of Australian public relations: Professionalisation and paradox. Public Relations Review, 35(4), 376-381.

Director-General. (2000). The Queensland Policy Handbook - Governing Queensland. Retrieved October 10, 2008. from http://www.premiers.qld.gov.au/library/pdf/policy.pdf.

EARC. (1993). Report on review of government media and information services. Brisbane: Electoral and Administrative Review Commission.

Education Queensland Salary Schedule. (2010). Retrieved from:

http://webcache.googleusercontent.com/search?q=cache:BdFLW9A3X68J:education.qld.gov.au/hr/re cruitment/administrative/docs/salaryschedule.xls+qld+gov+docs+salary+schedule \&cd=1\&hl=en $\& \mathrm{ct}=\mathrm{clnk} \& \mathrm{gl}=\mathrm{au}$.

Esser, F., Reinemann, C. \& Fam, D. (2001). Spin Doctors in the United States, Great Britain, and Germany. Metacommunication about Media Manipulation. The Harvard International Journal of Press/Politics, 6(16), 16-45

Fitzgerald, G. E. (1989). Report of a Commission of Inquiry Pursuant to Orders in Council. Brisbane: Queensland Government.

Gaber, I.(2000). Lies, damn lies ... and political spin. British Journalism Review, 11(1), 6-70.

Glenny, L. (2008). Perspectives of communication in the Australian public sector. Journal of Communication Management, 12(2), 152-168.

Gregory, A. (2008). Competencies of senior communications practitioners in the UK: An initial study. Public Relations Review, 34(3), 215-333.

Grundy, B. (1993). EARC's inquiry into government PR: A summary and appraisal. Australian Studies in Journalism, 2, 288-304.

Johnston, J. (2007). Media relations: Issues and strategies. Crows Nest, NSW: Allen \& Unwin

Lattimore, D., Baskin, O., Heiman, S. \& Toth, E. (2009). Public relations: The profession and practice ( $3^{\text {rd }}$ ed.). Boston: McGraw Hill.

L’Etang, J. (2009). Public relations and diplomacy in a gloablized world:

An issue of public communication. American Behavioral Scientist, 53(4), 607-626.

Lion, P. (2008, June 3). If you need spin, the doctor is in. Courier-Mail, p. 3.

Louw, E. (2005). The media and the political process. London: Sage.

MyCareer. (2008). Retrieved from http://content.mycareer.com.au/salary-centre/.

Orr, J. (1994). Politics, news management and monopolies - a consumer issue? In J. Schultz (Ed.). Not just another business (pp. 95-114). Leichhardt, NSW: Pluto Press Australia.

Parliamentary Committee for Electoral and Administrative Review. (1994). Report on review of government media and information Services. Brisbane: Legislative Assembly of Queensland.

Parliamentary Service Certified Agreement. (2007). Retrieved. from http://www.qirc.qld.gov.au/agreement_award/certified_agreements/cert_agreements/2007/ca11_ 2007.pdf.

Patching, R., \& Pearson, M. (2007). Government media relations: Spinning into focus. Paper presented at the 2007 Public Right to Know Conference, University of Technology, Sydney. 
Pearson, M., \& Patching, R. (2008). Government media relations: A 'spin' through the literature'. (MS \#1243). Retrieved from http://epublications.bond.edu.au/hss_pubs/228.

Phillis, B. (2004). An independent review of government communications. Retrieved from: http://www.cabinetoffice.gov.uk/media/cabinetoffice/corp/assets/publications/ reports/communications_review/final_report.pdf.

PRIA 'About us'. (2009). Retrieved from http://www.pria.com.au/aboutus/cid/2/t/aboutus

Queensland Audit Office annual report 2006-2007 - Strengthening accountability. (2007). Brisbane: Queensland Audit Office.

Queensland Budget 2008-2009. Budget highlights. (2008). Retrieved from http://www.budget.qld.gov.au/budget-papers/2008-09/budget-highlights-2008-09.doc.

Queensland Government A. (2008). Department of Premier and Cabinet. Retrieved from www.premiers.qld.gov.au/About_the_department/publications/corporate/.

Queensland Government B. (2008). Department of Premier and Cabinet. Retrieved October 102008 from http://www.premiers.qld.gov.au/About_the_department/About_us/divsworkunits/governance/Sta te_Services/Communication_Services/.

Queensland Government C. (2008). Department of Premier and Cabinet. Retrieved from http://www.premiers.qld.gov.au/about-us/our-key-people/ddg.aspx.

Queensland Government D. (2008). Disability and Community Care Services. Retrieved from http://www.disability.qld.gov.au/support-services/funding/guidelines/salary-on-costs.html.

Queensland Government E. (2008) Department of Premier and Cabinet. Retrieved from $\mathrm{http} / / / \mathrm{www}$.premiers.qld.gov.au/publications/categories/policies-andcodes/handbooks/ministerial-handbook.aspx.

The Queensland ministerial handbook - Governing Queensland. (2004). Retrieved from $\mathrm{http} / / \mathrm{www}$.premiers.qld.gov.au/publications/categories/policies-andcodes/handbooks/ministerial-handbook.aspx.

Question on notice. No. 685. (2008). Legislative Assembly.

Question on notice. No. 1149. (2008). Legislative Assembly.

Stockwell, S. (2007). Spin doctors, citizens and democracy. In S. Young (Ed.). Government communication in Australia (pp. 130-143). Melbourne: Cambridge University Press.

Smilmalis, L. (2010, January 17). Millions Spent on Spin Doctors. Daily Telegraph, p. 5.

Sunday Mail (2009, September 6). \$49m for PM's spin doctors. p. 24.

Ward, I. (2003). An Australian PR state? Australian Journal of Communication, 30(1), 25-42.

Wenham, M. (2006, December 6). PR at premium price - Hefty cost to polish up image. CourierMail, p. 15.

Mark Pearson is Professor of Journalism and director of the Centre for New Media Research and Education at Bond University, Queensland, Australia, and Hamish McLean is Senior Teaching Fellow at the same institution. This is a substantially revised version of a paper delivered by the first author at the Public Right to Know conference at the University of Technology, Sydney in 2008. The authors gratefully acknowledge funding from Bond University's Vice-Chancellor's Research Grant Scheme for this project and the comments of the anonymous reviewers. 